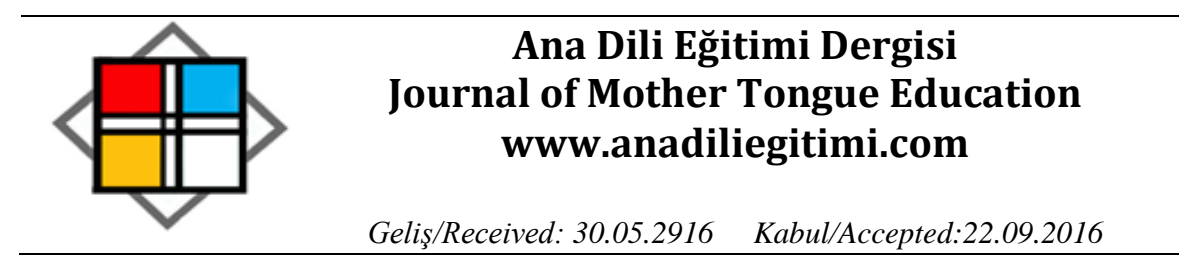

\title{
Sevim Ak`ın Öykülerinin Eğitsel İletileri ${ }^{1}$
}

\begin{abstract}
Serap UZUNER YURT
Tacettin ŞIMŞEK ${ }^{3}$

Öz

Günümüzde çocuğa ve eğitime verilen öneme paralel olarak çocuk edebiyatı alanında verilen eserlerin sayıları da artmıştır. Bu alana katkıda bulunan yazarlarımızdan biri de Sevim Ak'tır. Bu çalışmanın temel amacı, Sevim Ak`ı öykülerini eğitsel iletiler açısından incelemektir. Araştırma kapsamında incelenen materyali, Sevim Ak` ın Can Yayınlarından çıkan toplam 11 çocuk öykü kitabı oluşturmaktadır. Veriler doküman incelemesiyle elde edilmiştir. Verilerin anlamlandırılması sürecinde içerik analizi yöntemi kullanılmışır. Çocuk kitaplarındaki iletilerin eğitsel yönü dikkate alındığından dolayı kategoriler gelişim dönemlerine göre başlıklandırılmıştır. Öykülerde duygular ve duyguların ifadesine yönelik iletilerin işlenme sıklı̆ı $(\% 33,03)$ ilk sırada gelmiştir. Beraberinde eserlerde sırasıyla ahlaki değerlere $(\% 22,48)$, bilişsel gelişime $(\% 22,02)$, sosyal gelişime $(\% 12,84)$, öz bakım becerilerine $(\% 6,88)$, fiziksel görünüme yönelik $(\% 2,75)$ toplamda 218 iletiye yer verildiğ tespit edilmiştir. Yazarın öykülerinde işlediği eğitsel iletiler ve bunların işlenme sıklığı, bu iletileri okuyucuya iletme yöntemi ve kullandığı dil göz önüne alındığında, araştırmada kullanılan kitapların öğrencilere tavsiye edilebilir nitelikte olduğu söylenebilir.
\end{abstract}

Anahtar Kelimeler: Çocuk öyküsü, ileti, Sevim Ak, çocuk edebiyatı

\section{Educational Messages in Sevim Ak's Stories}

\begin{abstract}
Today, in parallel with the importance given to children and education, the works in children's literature have increased in number. One of the contributors to this field is Sevim Ak. The main aim of this study is to examine the stories of Sevim Ak in terms of educational messages. The materials analyzed in the study consist of 11 Sevim Ak children's storybooks published by the publisher Can Yayınları. The data were acquired through document review. In data analysis, content analysis method was used. As attention was paid to the educational aspect of the messages in the children's books, the categories were organized according to children's developmental periods. In stories, the frequency of the messages about the emotions and their expressions were in the first place $(\% 33,03)$. After that, in a total of 218 messages, there were messages about moral values $(\% 22,48)$, cognitive development $(\% 22,02)$, social progress $(\% 12,84)$, self-care abilities $(\% 6,88)$, and physical appearance $(\% 2,75)$ respectively. Considering the educational messages of the author and their frequency, the method of communicating those messages to the reader, and the language used, it can be concluded that the books used in the study are worthy of recommendation to children.
\end{abstract}

Key Words: Children's story, message, Sevim Ak, children's literature

\footnotetext{
${ }^{1}$ Bu çalışma "Sevim Ak`ın Öykülerinin Eğitsel Değeri" isimli doktora tezinin bir bölümünden oluşmaktadır.

${ }^{2}$ Yrd.Doç.Dr, Erzincan Üniversitesi, SHMYO, Çocuk Gelişimi Programı. Erzincan. suzuneryurt@gmail.com

${ }^{3}$ Yrd.Doç.Dr, Atatürk Üniversitesi, KKEF, Türkçe Eğitimi Anabilim Dalı.

Erzurum.tacsimsek@gmail.com
} 


\section{Giriş}

Çocuk edebiyatı ürünlerinin temel amacı, öğretmek değil, çocuklara duyarlılık kazandırmak, onların güzele yönelik duygularını geliştirmektir. "Edebî eserler hem bireysel hayatla, hem de sosyal hayatla ilgili olarak iyiye, güzele ve doğruya yönelme yolunda, yeni değerler kazandırma yolunda telkinlerde bulunur, insanları bunlar doğrultusunda eğitir" (Kavcar,1999:6). Yazar eserlerindeki iletiler aracılığıyla okuyucuya iyiyi, güzeli telkin eder.

Illeti yazarın okurla paylaşmak istediği asıl düşüncedir. "Kaynak tarafından oluşturulan içeriğin içindeki duygu, düşünce, önermelerin bütününe ileti ya da mesaj denir" (Güleryüz, 2002:161). Başka bir tanımda ise edebiyat yapıtlarında ileti için, sanatçının okurlarında yaratmak ya da oluşturmak istediği duygu ve düşünce ortaklığı şeklinde ifade edilir (Sever, 2008:140). Çocuk edebiyatı ürünlerinde işlenen temaların açık ya da örtük eğitsel bir ileti ile ilişkilendirilmesi mümkündür. Her tema, bünyesinde o tema ile bağlantılı bir iletiyi taşır. Yazarın, söz konusu temayı, çocuk okurlara iletiler sunmak için seçtiği söylenebilir.

Bu iletilerinde aktarım biçimi son derece önemelidir. "Türkçe öğretiminin amaçlarına ulaşabilmesi için Türkçenin anlatım olanaklarını ve kurallarını yansıtan yazınsal metinlere gereksinim vardır. Bu araçlar çocukların dil, anlam ve alımlama yeterliğine uygun, Türkçenin anlatım olanaklarını ve kurallarını yansıtan yazınsal metinlerdir. Bu metinlerde ileti doğrudan, açık bir biçimde verilmez. Yazarın okurla paylaşmak istediği duygu ve düşünceler, metnin dokusuna sindirdiği ipuçlarından da yararlanarak okur tarafından anlamlandırılı" (Sever, 2008: 17). Sever gibi Özdemir de iletilerin çocuklar için yazılmış eserlerde doğrudan verilmesi taraftarı değildir.

Yazınsal metinlerde ileti, önerme biçiminde ya da kesin bir yargıya dönüştürülmüş olarak verilmez. İleti, metnin dokusuna sindirildiği için metinlerdeki ileti örtüktür ve yazarla okurun paylaştığı, okurun kendi yaşantısına kattığı, bir durumun, bir sorunun aydınlatılmasına yöneliktir (Özdemir, 1995: 95). Fakat edebî metinlerdeki iletilerin örtük olması muhatabı olan çocukların kapasitesinin üzerinde bir anlatımın olması anlamına da gelmemelidir.

Çocuklar için yazılmış edebî eserlerde yer alan iletiler, çocuğun gelişim alanlarını olumlu etkilemeli, onun yaşam gerçeklerine uygun olmalı, sanatsal bir dille, doğrudan değil ama anlaşılır bir üslupla verilmelidir (Demirel, 2011: 58,59).

Nitelikli çocuk edebiyatı ürünleri çocukların eğitiminde etkili birer araç görevi üstlenir. Çocuk kitapları hangi temayı ele alırsa alsın, bir şekilde mutlaka çocuğun duygu, düşünce ve davranış gelişimine katkı sağlamayı amaçlar. Çocuk edebiyatı yazarları, işledikleri temalar ve vermek istedikleri iletiler yoluyla okurlarda olumlu değişikliklere zemin hazırlamak ve onların değerler dünyasını oluşturmaya çalışırlar. Öncelikle duygu, düşünce ve davranışların olumlu yönde değiştirilmesi 


\section{Serap UZUNER YURT, Tacettin ŞIMŞEK}

hedeflenir. Bu, yazarların edebî metinler aracılığıyla geleceğin toplumunu inşa etme ülküsüyle ilgilidir. Bu nedenle ülkemizde nitelikli çocuk edebiyatı metinleri iletileri bakımından çokça incelenmektedir (Dellal, 2010; Yakar, 2011; Demirbaş, 2012; Akçay ve Baş, 2015; Cesur ve Baş, 2015).

Bu doğrultuda çalışmanın temel amacı, Sevim Ak’ın öykülerinin eğitsel iletilerini tespit etmektir. Çalışma sonuçları yazarlara, Türkçe öğretimine ve öğretimcilerine ayrıca bu alanda ilgili araştırma yapacak olanlara yol gösterecek olması, bu araştırmayı ayrıca önemli kılmaktadır.

\section{Yöntem}

\section{Araştırmanın Modeli}

Araştırma, Sevim Ak`ın öykülerinin eğitsel iletilerini tespit etmek amacıyla yapılmıştır. Verilerin çözümlenmesi sürecinde nitel yollarla yazılı biçimdeki veriler toplanmış, belirli aşamalardan sonra sayılara dökülmüş ve böylece nitel veri nicelleştirilmiştir. Bu araştırmada Sevim Ak`ın öykülerindeki iletiler doküman incelemesiyle belirlenmiştir. Doküman incelemesi, araştırılması hedeflenen olgu veya olgular hakkında bilgi içeren yazılı materyallerin analizini kapsar. Nitel araştırmada doküman incelemesi tek başına bir veri toplama yöntemi olabileceği gibi diğer veri toplama yöntemleri ile birlikte de kullanıı (Yıldırım ve Şimşek, 2006:187). Doküman incelemesinin güçlü yönlerine ilişkin olarak Bailey (1982) yedi boyuttan söz eder: Kolay ulaşılamayacak özneler, tepkiselliğin olmaması, uzun süreli veya zamana yayılmış analiz, örneklem büyüklüğü, bireysellik ve özgünlük, göreli düşük maliyet ve niteliktir (Akt. Yıldırım ve Şimşek, 2006:190).

Bu çalışmanın araştırma problemi, "Sevim Ak`ın çocuklara seslenen öykülerinin eğitsel iletileri nelerdir?" sorusu üzerine kurulmuştur.

\section{Araştırmanın İnceleme Nesneleri}

Araştırma kapsamında incelenen materyali; Sevim Ak’ın Can Yayınlarından çıkan toplam 11 çocuk öykü kitabı olan Uçurtmam Bulut Şimdi, Karşı Pencere, Pembe Kuşa Ne Oldu, Penguenler Flüt Çalamaz, Toto ve Şemsiyesi, Mahalle Sineması, Dalgalar Dedikoduyu Sever, Sakız Kızın Günleri, Gökte Biri Var, Dörtgöz, Toto`nun Sınıfı, Sakız ve Aytaşı, Çilekli Dondurma oluşturmaktadır.

\section{Veri Toplama ve Analizi}

Araştırma kapsamında incelenen 11 kitap, basımlarını yapan yayınevinden son baskısı olmasına dikkat edilerek temin edilmiştir. Eserler araştırmacı tarafından birkaç kez okunmuştur. Verilerin anlamlandırılması sürecinde temel olarak içerik analizi yöntemi kullanılmıştır. İçerik analizinde temel amaç, toplanan verileri açıklayabilecek kavramlara ve ilişkilere ulaşmaktır. Bu amaçla toplanan verilerin önce kavramsallaştırılması, daha sonra da ortaya çıkan kavramlara göre mantıklı bir biçimde organize 
edilmesi ve buna göre veriyi açıklayan temaların saptanması gerekmektedir. Böylece, içerik analizi yoluyla veriler içinde saklı olabilecek gerçekleri ortaya çıkarmaya çalışılır. İçerik analizinde temelde yapılan işlem, birbirine benzeyen verileri belirli kavramlar ve temalar çerçevesinde bir araya getirmek ve bunları okuyucunun anlayabileceği bir biçimde organize ederek yorumlamaktır (Yıldırım ve Şimşek, 2006: 227). Metinlerdeki iletiler tespit edilmiş benzerlik ve farklılıklarına göre tematik bir kodlama yapılmıştır. Kodlamanın güvenirliğini belirlemek için araştırmada incelenen nesnelerden rastgele üçü seçilip bunların alan uzmanı tarafından tekrar kodlanması istenmiştir. Verilerin analizinde, iki bilim uzmanı tarafından ayrı ayrı yapılan kodlamalarda, Miles ve Huberman’ın (1994) güvenirlik formülüne göre öngördüğü düzeyin (\% 70) üzerinde, \% 93 oranında görüş birliği sağlanmıştır [görüş birliği/(görüş ayrılığı+görüş birliği)*100=97]. Bu tematik kodlama sonucu kategoriler oluşturulmuştur. Bu kategoriler şunlardır:

* Duygular ve Duyguların Ifadesine Yönelik Iletiler

*Sosyal Gelişime Yönelik iletiler

*Ahlaki Değerler ve Ifadelerine Yönelik iletiler

*Bilişsel Gelişime Yönelik İletiler

*Fiziksel Görünümle Illgili iletiler

*Öz Bakım Becerilerine Yönelik iletiler.

Elde edilen veri seti tekrar tekrar araştırmacı tarafından okunmuştur. Daha sonrasında belirlenen kategoriler ve bu kategorilere ait iletilerin alan uzmanları tarafından tekrar incelenmesi istenmiştir. Gelen görüşler doğrultusunda gerekli düzeltme ve değişiklikler yapılmıştır.

\section{Bulgular}

\section{Sevim Ak'ın Öykülerinde Eğitsel İletiler ïlişkin Bulgular}

Sevim $A k^{\prime} ı n$ öykülerinde de benzer düşüncelerle yer alan iletiler, çocuğun gelişim süreçlerine göre sınıflandırılabilir (Grafik 1). 


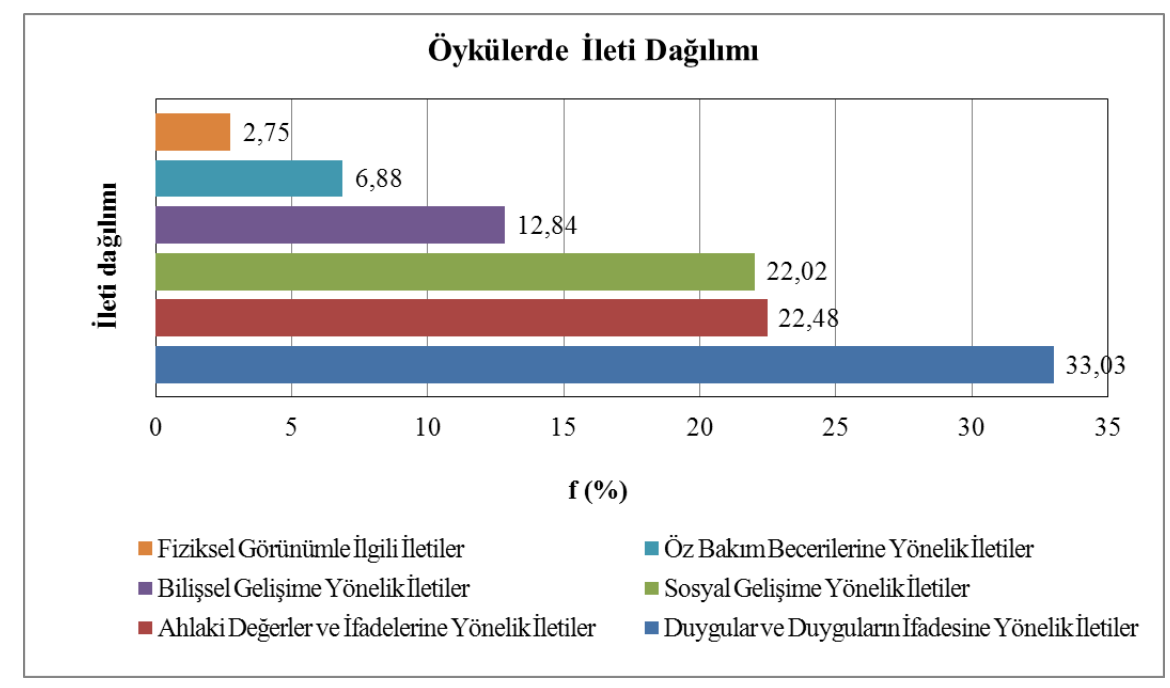

\section{Grafik 1. Öykülerde ileti Dağılımı}

Grafik 1 'de yazarın öykü kitaplarında en fazla duygular ve duyguların ifadesine yönelik iletilere $(\% 33,03)$, beraberinde sırasıyla ahlaki değerlere $(\% 22,48)$, bilişsel gelişime $(\% 22,02)$, sosyal gelişime $(\% 12,84)$, öz bakım becerilerine $(\% 6,88)$, fiziksel görünüme yönelik $(\% 2,75)$ toplamda 218 iletiye yer verdiği tespit edilmiştir.

\section{Duygular ve Duyguların İfadesine Yönelik iletilere ilişkin Bulgular}

Kitaplar çocuğun duygusal gelişiminde önemli bir uyarıcıdır. Bir kitabın çocuğun ilgisini çekmesi için, o kitabın bazı gereksinimlere yanıt vermesi gerekir. Bunların başında duygusal gereksinimler gelir. Duygular ve duyguların ifadesine yönelik iletiler ve bu iletilerin öykülerde işlenme oranı Grafik 2 'de gösterilmiş, daha sonra bu iletiler ile ilgili açıklamalara yer verilmiştir.

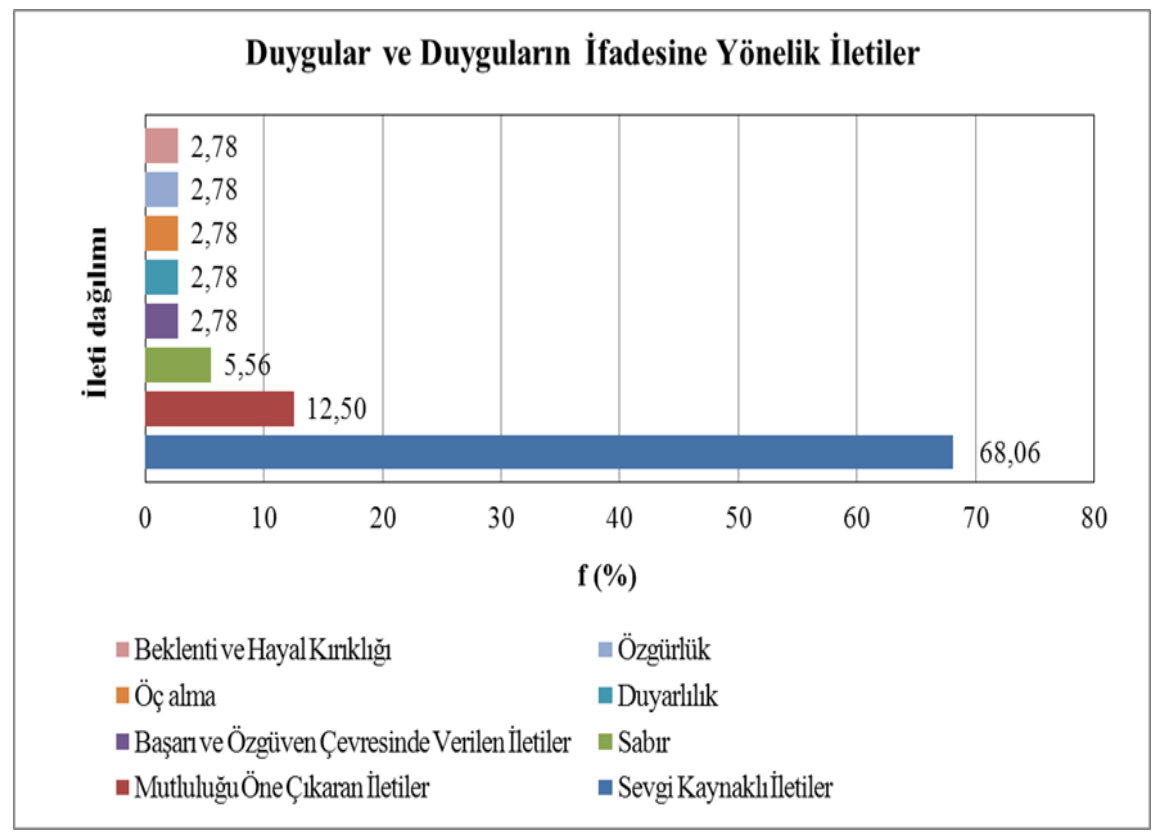

Grafik 2. Duygular ve Duyguların Ifadelerine Yönelik Iletilerin Dağılımı 
Grafik 2 incelendiğinde öykülerde 49 kez sevgi kaynaklı $(\% 68,06), 9$ kez mutluluğu öne çıkaran $(12,50), 4$ kez sabır mesajı veren (\%5,56), 2 kez ise başarı ve özgüven (\%2,78), duyarlılık (\%2,78), öç alma $(\% 2,78)$, özgürlük $(\% 2,78)$, beklenti ve hayal kırıklı̆ı $(\% 2,78)$ ile ilgili iletilere yer verildiği görülmektedir. Eserlerde çocuğun duygusal anlamda en temel gereksinimlerinden biri olan sevginin yüksek oranda işlenmesinin olumlu bir sonuç olduğu söylenebilir. Sevim Ak eserlerinde sevgi temasından beslenen iletilere çokça yer vermiştir. Yazar, doğadaki canlı ve cansız varlıklara duyulan sevgiden yola çıkarak çocuklara sevgiyi sezdirmeye çalışır.

Yazarın; arkadaş sevgisi, aile sevgisi, hayvan sevgisi, doğa sevgisi, öğretmen sevgisi ve yaşama sevgisine yönelik olarak eğitsel iletiler vermiştir.

Bir yanda insanlar, arkadaşı tarafından sevildiğini ve önemsendiğini anladığında mutlu olur iletisi okura verilirken (Kum Kaleler ve Bir Yalnız Deniz Feneri) diğer yanda arkadaşlık duygusunun fedakârlıkla bağlantısı kurulur ve çok sevdiği arkadaşının ölmemesi için kendi yüreğini vermeye hazır bir öykü kahramanı betimlenir (Açıkgöz ve Süs).

"Tanker fenere sevgi gösterince, fener de kendisini sevmiş. işe bakın! Kendini işe yaramaz, yaşlı köhne değil iyi yürekli, dost, yardımsever görüyormuş şimdi” (Ak, 2010:62).

Anneler Günü'nde güzel bir hediyeyle annesine sevgisini göstermek isteyen bir kız çocuğunun hikâyesi "Gözlerimi Geri Verin" adlı öyküde anlatııır. Bu öykü aracılığıyla çocuğun annesine olan sevgisinin cebindeki parayla ölçülemeyeceği, sevginin çok değerli hediyelerle değil, küçük de olsa anlamlı hediyelerle gösterilebileceği anlatılır.

"Ertesi sabah kahvaltı masasında hediyem başköşedeydi. Annem çayları koydu. Şekerleri ben koymak istedim. Babamla ikimize ikişer kaşık toz şeker... Annemin bardağına hediye paketinden bir kesme şeker" (Ak, 2011h:55).

\section{Ahlaki Değerler ve Ahlaki Değerlerin ifadelerine Yönelik iletiler}

Çocuklar için yazılmış edebî eserlerin muhatabında olumlu değer yargıları uyandırabilmesi gerekir. Sevim Ak'ta tutumluluk, paylaşma, yardımlaşma, hırsın zararları, önyargının yanlışlığı, kötü alışanlıklar, sözünde durma, bencillik, yalan, iyilik, özür dileme, emek, sorumluluk, faydalı olabilmek gibi başlıklar altında toplanabilecek iletilere sıklıkla rastlanır. 


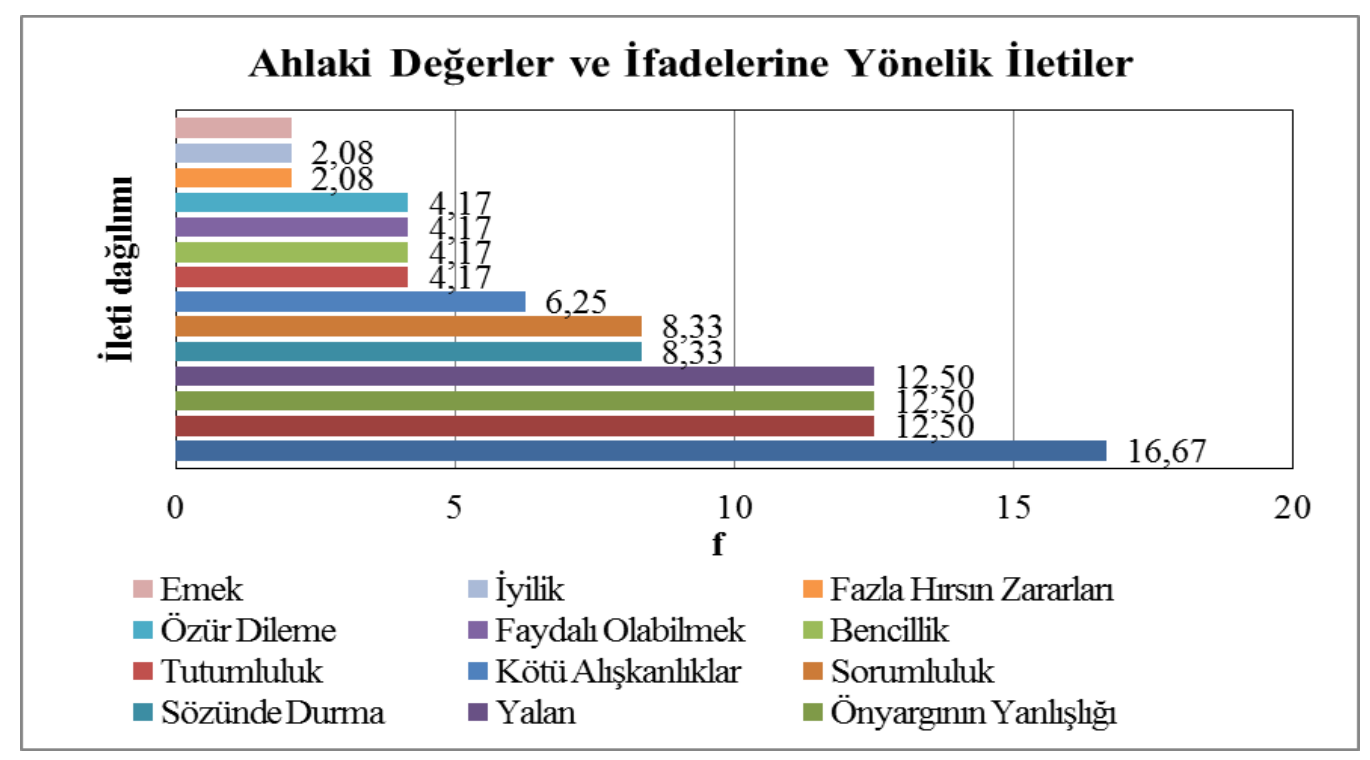

\section{Grafik 3. Ahlaki Değerler ve ifadelerine Yönelik Iletilerin Dağılımı}

Grafik 3 incelendiğinde öykülerde 8 kez yardımlaşma (\%16,67), 6 kez önyargının yanlışlığı (12,50), yalan ve paylaşma; 2 kez sözünde durma ve sorumluluk(\%8,33); 3 kez kötü alışkanlıklar (\%6,25), 2 kez faydalı olabilmek (\%4,1), bencillik, özür dileme ve tutumluluk, 1 kez ise fazla hırsın zararları $(\% 2,04)$, iyilik, emek ile ilgili iletilere yer verildiği görülmektedir. Bu bulgulardan hareketle iletilerin işlenme sıklığının az ama ahlaki değerlerle ilgili konu başlı̆̆ının fazla olduğunu söyleyebiliriz.

Yardımlaşma toplumda kaynaşma sevgi ve saygıyı artırma özelliği olması sebebiyle çocuk kitaplarında yardımseverlik gibi evrensel ve ahlaki değerler işlenmelidir. Yazar yardımlaşmanın birlik ruhu ile çalışma, topluma yönelik hareketler içinde olmak, bir toplum içerisinde yaşayan insanların aralarındaki yakınlaştırıcı bağları ve karşılıkı işbirliği ile ilgili durumlarını gösteren bir oluşum olduğu düşüncesindedir.

Yazar “Öyle Bir Gün” adlı öyküsünde yaşlılara yardım etmenin gereğini vurgular.

"Ben hamal falan değilim, sadece bir öğrenciyim. Bu hafta yaşlılar haftası da. Size yardım edeyim dedim."

"Sakız ve Haftanın Öyküsü" ve "Toto ve Şemsiyesi” nde çocuklar çevresindekilere yardım etmeyi çok sever. "Yağmurlu Bir Gün” öyküsünde Gülüş’ün halası sokak çocukları derneğinde yardım gönüllüsü olarak çalışır.

\section{Sosyal Gelişime Yönelik iletiler}

Çocuklarda sosyal gelişim aile bireylerinin birbiriyle olan iletişimiyle başlar, okul ve çevre ile devam eder. Sevim Ak da öykülerinde çocuğun sosyal çevresiyle olan ilişkilerinden yola çıkarak okura birçok mesaj vermeye çalışmıştır. "Edebiyat yapıtları yaratıldığı toplumun kültürel ve toplumsal 
değerlerini de yansıtır. Masal, öykü, roman gibi yaratılardaki kahramanların kendisiyle, çevresiyle, doğa ve toplumla yaşadıkları çatışmalar, toplumun benimsenen ya da karşı çıkılması gereken değerlerini, inançlarını okura sezdirir (Sever, 2008:65).

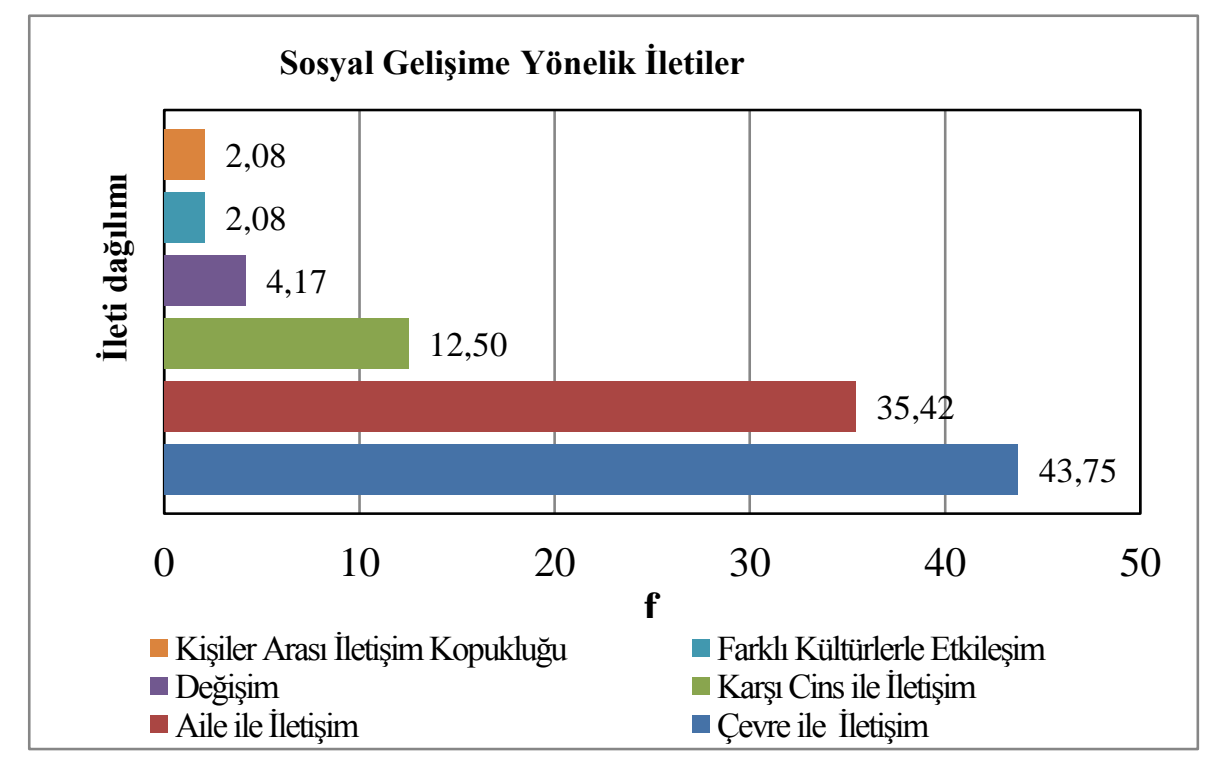

\section{Grafik 4. Sosyal Gelişime Yönelik iletilerin Dağılımı}

Grafik 4 incelendiğinde öykülerde 21 kez çevre ile iletişim $(\% 43,75), 17$ kez aile ile iletişim (\%35,42), 6 kez karşı cins ile iletişim (\%12,50), 2 kez değişim $(\% 4,17), 1$ kez farklı kültürlerle etkileşim $(\% 2,08)$, kişiler arası iletişim kopukluğu ile ilgili iletilere yer verildiği görülmektedir.

Çocuğun büyümesinde ve gelişmesinde ailenin çok önemli rolü vardır. Anne ve babanın birbirine uyumlu ve dengeli olması, çocuğun yetiştirilmesinde, tüm gereksinimlerin karşılanmasında sorumluluk alması, çocuğun kendisiyle ve dünya ile barışık, mutlu bir birey olmasına katkıda bulunur. Sevim Ak eserlerinde bu bilinçle hareket eder. Hatta onun öykülerindeki birçok iletinin çocuklardan ziyade ebeveynlere yönelik olduğu söylenebilir.

“Güneşi Gördüğüm Gün” öyküsünde çocukların, neyi nerede söyleyeceklerini bilmediği için anne ve babaları zor durumda bırakabilecekleri anlatıır. Aynı zamanda büyüklerin de dürüst olma konusunda çocuklarına örnek olmaları, çocuklarını yalan söylemeye özendirmemeleri gerektiğine işaret edilir.

Öyküde resim ödevini yapan çocuk, eve misafir geleceği için birden eşyalarını toparlayıp koltukların altına sıkıştıır. Anne, komşusuna kızının portresini beş dakikada çiziktirdiğini söyler. Kızı ise annesinin portresini yapana kadar harcadığı kâğıtları gösterir. Bu arada dolaptaki poşeti çıkarıp annesinin o portreyi yaparken harcadığı kâğıtları yatağına serer. Komşu kadın katıla katıla gülerken çocuk, annesinin bozulduğunu fark eder. Çocuk, annesinin hareketlerinden, yaptıklarının yanlış olduğunu ve cezalandırılacağını anlamıştır, çünkü buna benzer davranışları daha önce de yapmıştır. 
Serap UZUNER YURT, Tacettin ŞiMŞEK

Çocuklar, öğretmenleri tarafından tarafsızca değerlendirilmek, destek ve takdir görmek ister. Ak'ın eserlerinde olumsuz öğretmen davranışları ve bunların çocuklar üzerindeki etkileri gözler önüne serilir.

"Rol” adlı öyküde öğretmen, müzik aleti çalan öğrencisine "Kuyruğu kapıya sıkışmış kedi sesini çıkaran kim?" (Ak, 2011:15) diye bağırır.

\section{Bilişsel Gelişime Yönelik iletiler}

Sevim Ak'ta eserlerinde çocuklara bilişsel gelişimlerine katkıda bulunabilecek etkinliklerden, uygulamalardan bahseder, hayal kurmalarını öğütler.

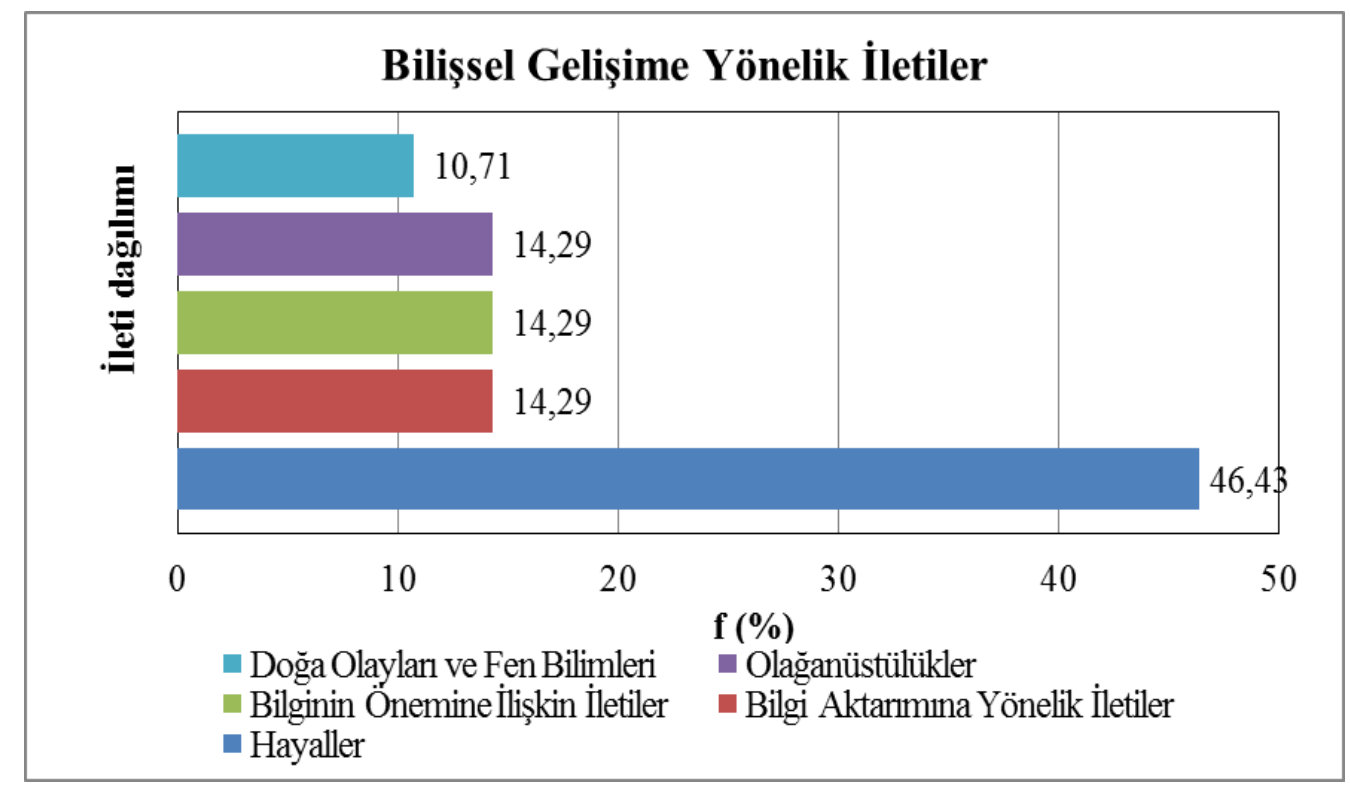

Grafik 5. Bilişsel Gelişime Yönelik iletilerin Dağılımı.

Grafik 1 incelendiğinde öykülerde 13 kez hayaller (\%46,43), 4 kez bilgi aktarımı (\%14,29), bilginin önemi ve olağanüstülükler; 3 kez doğa olayları ve fen bilimleri $(\% 10,71)$ ile ilgili iletilere yer verildiği görülmektedir. Edebî metinler, doğrudan bilgi verme amacı gütmezler. Bazen olayın anlatımından, bazen de olay kişilerinin dilinden birtakım bilgilerin okuyucuya verildiği görülür. Sevim $A k^{\prime} ı$ öykülerinde de dolaylı olarak bilgi aktarma örneklerine rastlanır.

Bireyin çevresindeki dünyayı anlama ve öğrenmesini sağlayan, aktif zihinsel faaliyetlerdeki gelişime bilişsel gelişim adı verilmektedir. Sevim Ak da eserlerinde çocuklara bilişsel gelişimlerine katkıda bulunabilecek etkinliklerden, uygulamalardan bahseder, hayal kurmalarını öğütler.

"Toto ve Güneş" isimli öyküde çocukların, hayallerini resimlerle gerçekleştirebileceği anlatılır. "Toto Venezuela'da" ise, hayal gücü fazla gelişmiş bir çocuk, arkadaşıyla yürüyerek Venezuela'ya gitmeye çalışır. 
Çocuklarının hayal güçlerinin ne denli geniş olabileceğini gösteren öykülerden biri de "Sakız ve Aytaşı'dır. Bu öyküde herkesin kendince farklı bir hayali vardır ve insanlar hayallerine ulaşarak mutlu olabilir iletilerine yer verilir.

“Açelya'nın Upuzun Bir Günü" de çiy ve kırağı oluşumuna yer verilir. "Kayıp Eşya Bürosu”nda bir bitkinin ancak güneşle gelişip güzelleşebileceği, "Huzurlu Gün"de ise ağaçların oksijen deposu olduğu anlatılır.

\section{Öz Bakım Becerilerine Yönelik iletiler}

Çocukların gelişimleri için gerekli olan deneyimlerin temeli ailede atılır. İlerleyen yaşlarda ise çevre faktörü devreye girer. Çocuk öz bakım becerilerini izleyerek, taklit ederek öğrenir. Bazen bu becerileri kazandırmada aileler yetersiz kalabilir. Edebî ürünlerde fazla öğretici olmamak kaydıyla temizlik, beslenme, spor gibi konulara yer verilebilir. Sevim Ak, öz bakım becerilerine yönelik olarak işlenme sıklık sırasıyla beslenme ve spor, sağlıklı yaşam, temizlik kuralları, öğle uykusu, sigara kullanmanın yanlışlığı, güneşten yararlanma konularına değinmiştir.

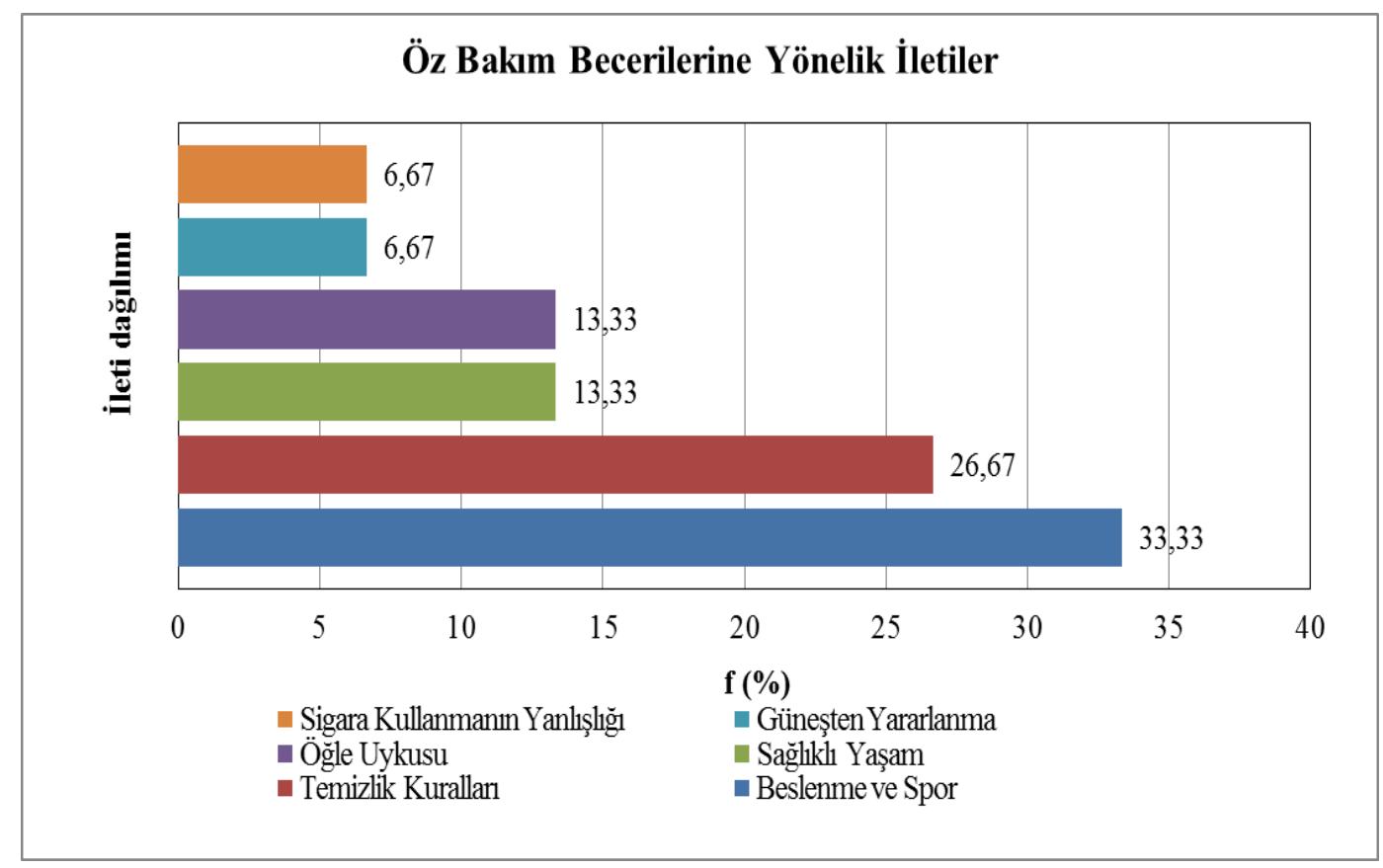

\section{Grafik 2. Öz Bakım Becerilerinin Yönelik iletilerin Dağılımı}

Grafik 6 incelendiğinde öykülerde 5 kez beslenme ve spor (\%33,33), 4 kez temizlik kuralları (\%26,67), 2 kez öğle uykusu $(\% 13,33)$ ve sağılılı yaşam; 1 kez güneşten yararlanma ve sigara kullanmanın yanlışlığı $(\% 6,67)$ ile ilgili iletilere yer verildiği görülmektedir.

"Çilekli Dondurma"da steril eldiven ve kâğıt maskeyle sokak köpeklerine bakım yapılır. "Bir Duvar Ressamı”nda bir simitçinin ellerinin, üstünün, başının tertemiz olması gerektiği vurgulanır. "Pembe Bisiklet" öyküsünde taranmamış saçları, yıkanmamış yüzüyle annesi tarafından masaya 


\section{Serap UZUNER YURT, Tacettin ŞiMŞEK}

oturulmasına izin verilmeyen çocuk, "Çöp"te ise sokakta eli yüzü leş gibi olan çocuğun bahçede temizlenmesi anlatıır. Bu, çocuk okuyuculara dolaylı yoldan temizlik alışkanlığı kazandırmaya yönelik bir tavrı yansıtır.

Çocukların sağlıklı büyümeleri için doğru beslenmeleri gerekir. Sütün çocuklar için zorunlu bir besin olduğuna inanan Ak, "Herkesin Bir Yıldızı Var", "Mahalle Sineması" ve "Toto Ne Yapıyorsun?" adlı öykülerinde kahramanların süt içtiğine dair cümlelere yer verir. Çocuk okurları, öykü kahramanlarıyla özdeşlik kurmaya ve dolaylı olarak süt içmeye davet eder.

\section{Fiziksel Görünümle IIIgili iletiler}

Yazarın öykülerinde fiziksel görünümle ilgili farklı kategoriler oluşturulabilecek iletilere rastlanmadığı için grafik oluşturulmamış.

Çocukları için fiziksel görüntü önemelidir. Boy, kilo, gözlük, saç rengi, şekli gibi fiziksel görüntüye ait özellikler çocukların kendilerini kötü hissetmelerine, olumsuz düşüncelere kapılmalarına neden olabilmektedir. Yazar kahramanları aracılığıyla okuruna birçok çocuğun gözlük kullandığını, boyunun kısa olduğunu ve bunların kötü değil aksine güzel farklılıklar olduğunu dile getirir. Fakat fiziksel görünümle ilgili ise toplamda altı ileti tespit edilmiştir. Yazarın bu doğrultudaki iletilerinin diğer gelişim alanlarına kıyasla çok fazla yer vermediğini söyleyebiliriz.

"Bir Çığlık" da boyunun kısa olduğunun ikide birde söylenmesine sinirlenen öykü kahramanı aracılı̆̆ıyla çocukların, fiziksel özelliklerinden dolayı utanç duyup üzülebilecekleri ifade edilir. "Sakız ve Aytaşı" nda ise kısa boylu olmanın çok şikâyet edilecek bir şey olmadığı iletisi verilir.

Kişi, alay edileceği endişesiyle fiziksel görünümüne dikkat etmeye çalışır. Bu durum "Dörtgöz" adlı öyküde gözlük takacağı için arkadaşlarının onunla alay edeceğini, babasının bütün arkadaşlarının gözlüklü olması nedeniyle babasının onu anlamayacağını düşünen kahramanımız aracılığıyla okura sunulur. Aynı öyküde sorunun çözümü için baba, başarılı insanları kızına örnek gösterir.

"Babam haklıydı. Düşünürler, bilim adamları, ressamlar, yazarlar, devlet büyükleri hep gözlüklüydü. Benim de gözlüğüm var. Hem de bu yaşta" (Ak, 2011b:7).

\section{Sonuç ve Tartışma}

Çocuk kitapları, ruhsal ihtiyaçların karşılanmasında ve bütün gelişim alanlarını destekler niteliktedir diyebiliriz. Bu nedenle yazarın vermek istediği mesaj ve bunu aktarım şekli önemlidir. Birçok kültürde değerleri iletmede çok önemli ve etkili bir yol hikâye anlatımıdır ve bu iletim çocuk kitaplarıyla yapılmaktadır (Kortenhaus ve Demarest, 1993).

Nitelikli çocuk kitapları çocuğun ana dilini en iyi şekilde öğrenmesini sağlar (Aslan, 2007; Binyazar, 1983; Çotuksöken, 2003; Russell, 1997; Sever, 2008;). Beraberinde çocuğun kişisel, duygusal 
ve bilişsel gelişimine katkıda bulunur (Alpöge, 2003; Çotuksöken, 2003; Gander ve Gardiner, 2001; Sever, 2008). Öyküler ve romanlar çocukların çevrelerini ve yaşadıkları toplumun değerlerini öğrenmesini sağlar (Sever 2008). Böylece gelecek nesillere bu değerleri taşımak için sosyalleşme aracı olarak hizmet eder.

Bu çalışmada Sevim Ak’ın öykü kitaplarındaki iletiler çocukların gelişim alanlarına göre incelenmiş ve alt başlıklar oluşturulmuştur. Sınıflandırma Duygular ve Duyguların Ifadesine Yönelik Iletiler, Ahlaki Değerler ve Ifadelerine Yönelik İletiler, Sosyal Gelişime Yönelik Iiletiler, Bilişsel Gelişime Yönelik İletiler, Fiziksel Görünümle İlgili İletiler, Öz Bakım Becerilerine Yönelik Illetiler şeklinde yapılmıştır. Öykülerde duygular ve duyguların ifadesine yönelik iletiler işlenme sıklığı açısından ilk sırada gelmiştir.

Çocuk dinlediği öykü ile duygusal yönden özdeşleşir. Başkalarının aynı duyguları yaşadığını görür. Duygu paylaşımı olur, dünyayı başkaları açısından da görmeye başlar. Yaşadığı ve yaşayacağı duygusal olaylardan nasıl davranacağını daha önce okunan öykülerle hazırlık yapmış olur. İfadesi zor ve soyut olan duygular öyküler yolu ile somutlaşır. Ak`ın duygu ağırıklı öykülerinde 49 kez sevgi merkezli iletilere (aile, arkadaş, hayvan, sanat, öğretmen, yaşama sevgisi vb.) yer vermesi bu anlamda önemlidir. Yurttaş`a (1997, Akt. Gökçe ve Sis, 20011) göre "çocuk kitaplarında ele alınması gereken konular "sevgi" kaynağından beslenmelidir. Çünkü çocuk, sevgiyle büyümesi gereken varlıktır. Çocuk kitabı yazarları da öncelikle sevgi ustası olmalıdır. Ak gibi birçok yazar bu gerçeği görmüş (Gülten Dayıoğlu, Muzaffer İzgü, Mustafa Ruhi Şirin) olumlu bir bakışla sevgi temalı eserler vermiştir (Barış, 2011; Özaslan, 2012; Yakar, 2011).

Yazar ahlaki gelişimi destekleyici konulara da kitaplarında fazlaca yer vermiştir. Çocukların bilişsel yapıları, kuralları ve ahlak ilkelerini anlamaya yeterli değildir (Senemoğlu, 2012, s.32). Çocukların edebî ürünlerindeki kahramanları kendilerine örnek almaları, kahramanlarla özdeşim kurmaları onlar için soyut olan ahlaki öğretileri anlamalarına yardımcı olacağı bilinen bir gerçektir. Ak `ın öykülerinde ahlaki değerler çerçevesinde başta yalan olmak üzere faydalı olabilmek, önyargının yanlışlığı, tutumluluk, sorumluluk, bencillik, fazla hırsın zararları, emek, sözünde durma, yardımlaşma, iyilik, kötü alışkanlıklar, paylaşmaya yönelik iletilere yer verdiği tespit edilmiştir.

Yazarın "Sosyal Gelişime Yönelik Iletiler" inin başında çevre ile iletişim teması gelmektedir. Çocukların sosyalleşmeye başladığı ilk çevre ailedir. Ama Ak`ın öykülerinde aile ile iletişim ikinci sırada gelmektedir. Bunun nedeni yazarın öykülerinin kahramanlarının dışa dönük, sosyal hayatın içinde, yetişkinlerle arkadaşlık kurabilen çocuklar olmasıdır. Karşı cinse duyulan ilgi, değişim, farklı kültürlerle etkileşim bu başlık altında tespit edilen diğer konulardır. 


\section{Serap UZUNER YURT, Tacettin ŞiMŞEK}

Bilişsel gelişime yönelik iletilerin işlenme sıklığına baktığımız zaman bilgilerin önemine ilişkin iletiler ilk sırayı almıştır. Ak çocukların bilişsel anlamda gelişmeleri için, bilgi edinmelerini, okula gitmeleri gerektiğini, hayal kurmalarını, fen ve doğa olaylarıyla ilgilenmelerini öğütler. Sever (2008) edebiyat ürünlerinin çocukların düşünme, karşılaştırma eleştirme gibi bilişsel süreçlerini işleten, onların insan ve yaşam gerçekliğini sanatçı bakış açısıyla tanımalarına ve değerlendirmelerine olanak sağladığını belirtir.

Çocukların gelişimleri için gerekli olan deneyimlerin temeli ailede atılır. Ilerleyen yaşlarda ise çevre faktörü devreye girer. Çocuk öz bakım becerilerini izleyerek, taklit ederek öğrenir. Bazen bu becerileri kazandırmada aileler yetersiz kalabilir. Edebî ürünlerde fazla öğretici olmamak kaydıyla temizlik, beslenme, spor gibi konulara yer verilebilir. Sevim Ak, öz bakım becerilerine yönelik olarak işlenme sıklık sırasıyla beslenme ve spor, sağlıklı yaşam, temizlik kuralları, öğle uykusu, sigara kullanmanın yanlışlığı, güneşten yararlanma konularına değinmiştir. Ak`ın eserlerindeki iletilerle ilgili alt başlıklara çocuk kitaplarının eğitsel iletilerini inceleyen benzer çalışmalarda da rastlanmıştır (Barış, 2011; Erdi, 2008; Özaslan, 2012; Yakar, 2011). Bu sonuçlardan hareketle çocuklara yönelik eserler veren yazarlar, çocuk edebiyatının işlevini sadece okuyucuyu eğlendirme, güzellik duygusu uyandırma olarak görmemekte, olumlu davranışlar kazandırmanın kaygısını da duymakta ve eserlerini de bu yönde kaleme almaktadırlar. Bu yazarlardan biri olan Ak da iyi bir çocuk kitabı nasıl olmalı sorusunu şu şekilde yanitlar:

Çocuğun kolayca empati kurabileceği, kolayca konusunun içine girebileceği, rahat anlaşılacak şekilde, yalın bir dile sahip olmalıdır. Çocuklar, kendilerini bir serüven kapsamında, güzel ve akılııa bir metinin satır aralarından kendisine uygun mesajlar üretebildiğinde, o metin içerisinde dolaşmaktan hoşlanır. Hayatlarında sık sık karşılaştıkları küçücük olaylar bile, çocuklar için uygun bir dille anlatıldığında, oldukça ilgi çekici olabilir (Söyleşi, 2013).

Çalışmada sonuç olarak şunlar söylenebilir:

1. Yazar, öykülerinde eğitsel iletileri okuyuculara öğüt verir gibi değil de yaşantılar aracılı̆̆ıyla iletmektedir.

2. Yazar, öykülerinde olumlu yönde eğitsel iletiler vermekte, bu iletileri okuyucuya doğrudan iletmek yerine örtük biçimde vermeyi tercih etmektedir.

3. Yazar öykülerinde eğitsel iletileri işlerken hitap ettiği yaş grubunun içinde bulunduğu dönemi dikkate alarak onların anlayabileceği durumları ve kişileri öykülerinde konu edinmektedir.

4. Yazarın öykülerinde millî ve manevi değerlerle ilgili iletilere yer vermediği, evrensel değerleri tercih ettiği tespit edilmiştir 
5. Yazarın öykülerinde işlediği eğitsel iletiler ve bunların işlenme sıklığı, bu iletileri okuyucuya iletme yöntemi ve kullandığı dil göz önüne alındığında, araştırmada kullanılan kitapların öğrencilere tavsiye edilebilir nitelikte olduğu belirlenmiştir.

\section{Öneriler}

Bu sonuçlar doğrultusunda belirlenen öneriler şöyle sıralanabilir:

- Yazarın diğer eserleri de eğitsel iletileri açısından incelenebilir.

- Diğer çocuk edebiyatı yazarlarının eserleri de eğitsel iletileri açısından incelenebilir.

\section{Kaynaklar}

Akçay, S., Baş B. (2015).Samet Behrengi'nin hikâyelerindeki eğitsel iletiler üzerine bir araştırma. Ana Dili Eğitimi Dergisi, 3(3), 77-90.

Akyol, H. (2006). Yeni programa uygun Türkçe öğretim yöntemleri, Ankara: Kök. Yayıncılık.

Aslan, C. (2007). Yazınsal nitelikli çocuk kitaplarının çocuğun okuduğunu anlama ve yazılı anlatım becerilerine etkisi. Yayımlanmamış doktora tezi. Ankara Üniversitesi Sosyal Bilimler Enstitüsü, Ankara.

Barış, G. (2011). Gülten Dayıoğlu'nun çocuk romanlarındaki eğitsel iletiler. Yayımlanmamış yüksek lisans tezi. Abant İzzet Baysal Üniversitesi Sosyal Bilimler Enstitüsü, Bolu.

Binyazar, A. (04-06 Ekim 2006). Çocuk kitaplarında yazınsallık. II. Ulusal Çocuk ve Gençlik Edebiyatı Sempozyumunda sunulmuş bildiri, Ankara.

Cesur, E., Baş B. (2015). Mavisel Yener'in çocuklara yönelik öykülerindeki eğitsel iletiler üzerine bir araştırma. Ana Dili Eğitimi Dergisi, 3(3), 64-76.

Çotuksöken, Y.(2003). Anadili öğretiminde edebiyatın yeri ve işlevi. Çağdaş Türk Dili 184,s.148-151.

Dellal, M. (2010). Çocuk edebiyatında öykü türünün çocuğun kavram gelişimine etkileri üzerine bir Araştırma (Gülten Dayıoğlu örneği). Yayımlanmamış yüksek lisans tezi. Afyon Kocatepe Üniversitesi Sosyal Bilimler Enstitüsü, Afyonkarahisar.

Demirbaş, T. (2012). Çocuk edebiyatı eserlerinin 6. sınıf öğrencilerinin karakter gelişimine etkisi.

Yayımlanmamış yüksek lisans tezi. Abant İzzet Baysal Üniversitesi Sosyal Bilimler Enstitüsü, Bolu.

Demirel, Ş. (Editör). (2011). Edebi metinlerle çocuk edebiyatı. (2. Basım). Ankara: Pegem A Yayıncılık.

Dilidüzgün, S. (1996). Çağdaş çocuk yazını. İstanbul: Yapı Kredi Yayınları.

Emre, A. C. (2000). Çocuklara Hikâye Anlatmak Sanatı, İstanbul: Millî Egitim Yayınevi.

Erdi, A. (2008).Türkiye'de 1980-1985 ve 2000-2005 yılları arasındaki çocuk kitaplarında eğitsel iletiler (karşılaştırmalı bir çalışma). Yayımlanmamış doktora tezi. Marmara Üniversitesi Eğitim Bilimleri Enstitüsü, i̇stanbul.

Gander, M. J. ve Gardiner, H.W. (2007). Çocuk ve ergen gelişimi. Ankara: Imge Kitabevi.

Gökçe, B ve Sis, N. (2011). Gülten Dayıoğlu'nun çocuk öykülerinin “hikâye haritası” yöntemine göre incelenmesi ve genel bir değerlendirmesi. Turkish Studies, 6(3), s. 1925-1949 


\section{Serap UZUNER YURT, Tacettin ŞIMŞEK}

Güleryüz, H.(2002). Yaratıcı çocuk edebiyatı, Ankara: Pegem A Yayınları.

Kavcar, C. (1999). Edebiyat ve eğitim. Ankara: Engin Yayıncılık.

Kortenhaus, C.M.,andDemarest, J. (1993). Gender role stereotyping in children's literatüre, A Journal of Research 28, 219-320.

Kozikoğlu, K. T. (2012). Çocuklara hayal kurdurtan yazar. Sevim Ak'la söyleşi. Sabah Gazetesi Kitap Eki, “http://www.sabah.com.tr/Kitap/ 2012/02/17/cocuklara-hayal-kurdurtan-yazar" (Erişim:10.03.2013).

Miles, M. B. \& Huberman, A. M. (1994). Qualitative data analysis: An expanded sourcebook. (2.baskı). London: Sage Publication.

Özaslan, P. (2012). Muzaffer İzgü’nün çocuklara yönelik hikâye ve romanlarındaki eğitsel iletiler.

Yayımlanmamış yüksek lisans tezi. Mehmet Akif Ersoy Üniversitesi Sosyal Bilimler Enstitüsü, Burdur.

Özdemir E. (199 ). Yazınsal türler. Ankara: Bilgi Yayınevi.

Russell, D. L. (1997). Literature for children. New York: Longman.

Senemoğlu, N. (2012). Gelişim öğrenme ve öğretim kuramdan uygulamaya. (21. Baskı). Ankara: Pegem A Akademi.

Sever, S. (2008). Çocuk ve edebiyat. (5. Basım). İzmir: Tudem Yayıncılık.

Yakar, Y. M. (2011). Mustafa Ruhi Şirin'in Türk çocuk edebiyatındaki yeri ve eserlerinin eğitsel değeri üzerine bir inceleme. Yayımlanmamış doktora tezi. Atatürk Üniversitesi Eğitim Bilimleri Enstitüsü, Erzurum.

Yalçın, A. ve Aytaş, G. (2002). Çocuk edebiyatı. Ankara: Akçağ Yayınları.

Yıldııım, A. ve Şimşek, H. (2006). Sosyal bilimlerde nitel araştırma yöntemleri. (5. Basım). Ankara: Seçkin Yayıncılık. 